\title{
Phosphorus sorption capacities in a headstream landscape- The pond chain structure
}

\author{
FU Qiang, YIN Cheng-qing*, SHAN Bao-qing \\ (State Key Laboratory of Environmental Aquatic Chemistry, Research Center for Eco-Environmental Sciences, Chinese Academy of Sciences, Bcijing \\ 100085, China. F-mail: cqyin(a)rcees.ac cn)
}

\begin{abstract}
Understanding phosphorus sorption phenomena in different wetland sediments is important in controlling the P output in headstream watersheds. The pond chain structure (PCS) is widespread in the headstrcam agricultural watersheds in the southeast of China. Phosphorus sorption characteristics were determined for pond surface sediments $(0-12 \mathrm{~cm})$ along a pond chain structure in Liuchahe watershed of Chaohu Lake. Results showed that $\mathbf{P}$ sorption capacities (expressed by $\mathbf{P}$ sorption index (PSI)) varied both with the landscape position of the ponds and sediment depth. From foothill ponds to riverside ponds the P sorption capacities indicated a significant gradient variability. The higher elevation ponds showed greater sorption capacities, and with the pond elevation decline, $P$ sorption capacities gradually decreased. Some physico-chemical properties, such as $\mathrm{pH}$, oxalate-extractable $\mathrm{Fe}_{\mathrm{c}}\left(\mathrm{Fe}_{\mathrm{ix}}\right)$, organic matter (TOC) and Mehlich I-extractable $\mathrm{Ca}, \mathrm{Mg}$ of pond sediments also indicated significant gradient variability from high elevation ponds to low elevation ponds. $\mathrm{Fe}_{\mathrm{wx}}$ was the sediment parameters most highly positively correlated with PSI and was the key factor in controlling $P$ sorption capacity in the pond chain structure $(r=0.92, p<0.001)$. Long-term hydrologic and sediment inputs can affect the distribution of sediment constituents and further affect the $P$ sorption capacity. Making the best of the spatial difference of sorption capacities of ponds in watersheds to control nonpoint source $P$ pollutant is necessary.
\end{abstract}

Keywords: pond; sediment; adsorption; spatial variability; nonpoint source

\section{Introduction}

The nonpoint source $P$ pollutants play a significant role in eutrophication processes in the southeast of China. Nonpoint sources pollution from agricultural regions account for more than half of the phosphorus load in many water bodies (Linker et al., 1996). Wetlands in watersheds are known to improve water quality by removing both particulate and dissolved $P$ from incident surface and subsurface waters (Walbridge, 1993; Wang el al., 2002).

The multipond system is an artificial pond system, which has existed for a long time in China. It is distinguished by its water retention and wide-distribution in Chinese agricultural watersheds (Yin et al., 1993). As a traditional hydraulic enginecring, its main function has been irrigation. Studies have shown that the multipond system can effectively retain nutrients from agricultural lands and reduce the nonpoint source pollution (Yin et al., 1993; Jin et al., 1992; Yan el al., 1998).

As the basic linking units of the multipond system, the pond chain structures (PCS) are composed of several large ponds and linked by ditches, like a pond chain. Their situations are generally from foothill to riverside. It has been shown that such arrangements of ponds could create special hydrological conditions (Shan el al., 2002), under which, P sorption capacity should be further researched.

In wetlands, long-term $\mathrm{P}$ retention is generally believed to be controlled by two main processes: a physical process, i.e. deposition of sediment and particulate organic $\mathrm{P}$; a chemical process, i.c. sorption of dissolved phosphate (Axt and Walbridge, 1999). Amounts of $\mathrm{P}$ can be stored with the sedimentation of soil particles in the multipond system (Yan et al., 1998), and these sediments can also further adsorb nonpoint source $P$ pollutants.

Some researches have shown that $\mathrm{P}$ sorption capacity is variously related to sediment constituents. Such as in the acid wetland sediments, P sorption was significantly correlated with amorphous $\mathrm{Fe}$ and $\mathrm{Al}$ content (Richardson, 1985; Lockaby and Walbridge, 1998). Hydrated $\mathrm{Fe}$ oxides associated with $\mathrm{Al}$ and organic matter in gel complexes have been shown to control inorganic P sorption in sediments (Axt and Walbridge, 1999; McCallister and Logan, 1978). In alkaline soil, the P sorption was probably controlled by Ca or Mg minerals (Goldberg and Sposito, 1985). However, there has not been any research to analyze the controlling factor and spatial variability of $P$ sorption in the multipond system in the southeast of China.

Spatial variability of $\mathrm{P}$ sorption capacities of wetland sediments in watersheds has not been well researched. The key factor controlling $\mathrm{P}$ sorption capacily in the multipond system was also not clear. In this study, we used the PCS to research (1) the spatial variability of $\mathrm{P}$ sorption capacity in PCS under the long-term hydrological conditions in the experimental watershed, and (2) the main controlling factors of $P$ 
sorption capacity in PCS.

\section{Materials and methods}

\subsection{Study sites}

This study was conducted in an experimental agricultural watershed called Liuchahe watershed in Chaohu Lake in 2003. Chaohu Lake is one of the 5 largest freshwater lakes in China and has suffered from intense eutrophication for a long time (Tu et al., 1990). The Liuchahe watershed is located on the northern bank of Chaohu Lake, and covers $691.6 \mathrm{hm}^{2}$ with a typical landscape of a multipond system. There are 193 artificial ponds with a $43.2 \mathrm{hm}^{2}$ of area of the ponds. The mean depth is $1.5 \mathrm{~m}$ and surface area is from 0.01 to $1 \mathrm{hm}^{2}$. These ponds can store the nonpoint source runoffs coming from ambient land uses.

The Liuchahe watershed can be divided into 12 subwatersheds. The subwatershed is an independent geographical unit in the watershed. Only when the great irrigation events happen (such as pumping water from the Chaohu Lake), the water exchange between the subwatersheds can happen. Generally, surface runoffs can flow only between the ponds in the subwatershed. In the subwatershed, from foothill to subwatershed outlet (near the riverside), 3-5 large ponds are distributed like a chain at the valley plain and usually surrounded by rice fields. There are several ditches between these ponds used for irrigation. These ponds and ditches form a pond chain structure in the subwatershed. PCS is the basic unit of the multipond system and is widespread in the headstream agricultural watersheds in the southeast of China.

In this study, Baojiatang subwatershed was selected to research the sorption abilities of the pond chain structure. This subwatershed has an area of 38.4 $\mathrm{hm}^{2}$. The types of land use are forests $(21 \%)$, nonirrigated farmlands $(17.4 \%)$, ricefields $(53.6 \%)$, and ponds (8\%). From foothill to subwatershed outlet, 5 main ponds are distributed like a chain. There are ditches between these ponds. According to the pond situation, from foothill to the subwatershed outlet, the serial number of these ponds is Pond 1, Pond 2, Pond 3, Pond 4 and Pond 5 (Fig. 1). Their characteristics are shown in Table 1.

When rainfall events happen, storm runoffs from the ambient land uses can flow into the pond chain structure. During this process, water, soil particles and phosphorus can be stored, accumulated and adsorbed in the ponds. Only during great precipitation events, the water can effuse from ponds and flow through each pond until flow out of the subwatershed (Shan $e t$ al., 2002).

Table 1 The pond characteristics of the pond chain structure (PCS) in Baojiatang subwatershed

\begin{tabular}{|c|c|c|c|c|c|c|c|}
\hline Pond & Area, $\mathrm{m}^{2}$ & $\begin{array}{c}\text { Elevation, } \\
\mathrm{m}\end{array}$ & $\begin{array}{c}\text { Mean } \\
\text { depth, } m\end{array}$ & $\begin{array}{l}\mathrm{TP} \text { in pond water, } \\
\mathrm{mg} / \mathrm{L}\end{array}$ & $\begin{array}{c}\text { Sediment } \\
\text { thickness, m }\end{array}$ & Main aquatic plant and coverage & Ambient land use \\
\hline Pond 1 & 2275 & 36.1 & 1.51 & $0.015 \pm 0.009$ & $0.10-0.18$ & Alternanthera philoxeroitle $(10 \%)$ & Forest \\
\hline Pond 2 & 2480 & 29.0 & 1.50 & $0.067 \pm 0.013$ & $0.15-0.25$ & Juncellus $(2 \%)$ & Rice \\
\hline Pond 3 & 7550 & 23.0 & 1.48 & $0.112 \pm 0.010$ & $0.20-0.30$ & No aquatic plant & Rice \\
\hline Pond 4 & 5850 & 17.1 & 1.43 & $0.171 \pm 0.035$ & $0.20-0.29$ & $\begin{array}{c}\text { Alternanthere philoxeroide }(44 \%) \\
\text { Phragmites communis }(12 \%)\end{array}$ & Rice \\
\hline Pond 5 & 6500 & 13.8 & 1.45 & $0.142 \pm 0.062$ & $0.15-0.28$ & $\begin{array}{c}\text { Alternanthera philoxeroide }(51 \%) \\
\text { Phragmites communis }(2 \%)\end{array}$ & Rice \\
\hline
\end{tabular}

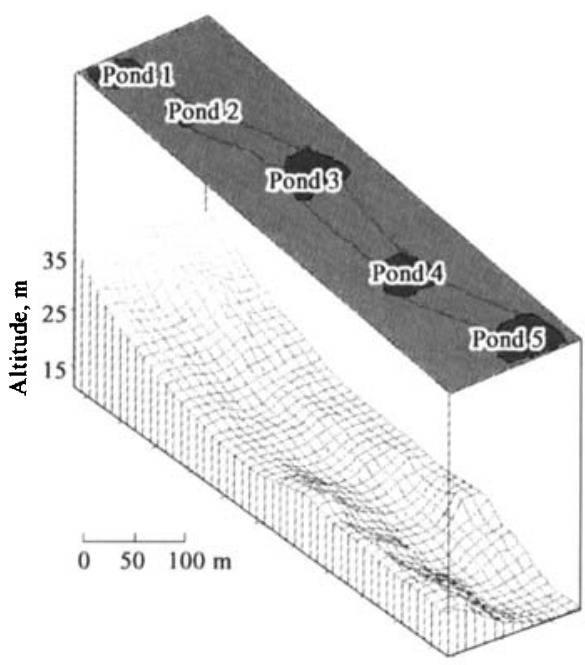

Fig.l Multipond system in Liuchahe watershed and the pond chain struclure (PCS) in Baojiatang subwatershed

\subsection{Sample collection}

Triplicate sediment cores (ca.12 cm depth) were obtained from representative locations of each pond in Baojiatang subwatershed using polyvinyl chloride pipe. Undecomposed organic debris on the surface of the sediments, such as leaves or plant residue, was removed. From top layer to bottom layer, a plastic knife was used to divide the sediment cores into 2 layers, the top organic layer $(0-3 \mathrm{~cm})$ and subsurface layer $(3-12 \mathrm{~cm})$. The sediment samples were then immediately homogenized and air-dried. The dry samples were crushed to pass through a 20-mesh sieve to form the initial sediment samples. The samples were placed in sealed plastic bags and kept in darkroom until chemical analysis.

\subsection{Physico-chemical analysis}

Oxalate-extractable $\mathrm{Fe}, \mathrm{Al}$ and $\mathrm{P}$ were determined by the method described by Bao (2000). 
$1 \mathrm{~g}$ sediment samples were extracted with $50 \mathrm{ml}$ of 0.1 $\mathrm{mol} / \mathrm{L}$ oxalic acid and $0.175 \mathrm{~mol} / \mathrm{L}$ ammonium oxalate $(\mathrm{pH}=3.5)$. After $4 \mathrm{~h}$ continuously shaking on an end-over-end mechanical shaker, the supernatant was filtered through a $0.45-\mu \mathrm{m}$ membrane filter. The filtrates were analyzed for $\mathrm{P}, \mathrm{Fe}$ and $\mathrm{Al}$ using inductively coupled argon plasma spectrometry (Optima $2000 \mathrm{DV}$ ).

Mehlich I-extractable $\mathrm{Ca}$ and $\mathrm{Mg}$ were determined by the double acid method (Bao, 2000). The sediment samples were extracted with a weak acid mixture $\left(0.05 \mathrm{~mol} / \mathrm{L} \mathrm{HCl}+0.0125 \mathrm{~mol} / \mathrm{L} \mathrm{H}_{2} \mathrm{SO}_{4}\right)$ at a sediment/solution ratio of $1: 5$. After $5 \mathrm{~min}$ shaking on a mechanical shaker, the suspension was filtered through a $0.45-\mu \mathrm{m}$ membrane filter. The filtrates were analyzed for $\mathrm{Ca}$ and $\mathrm{Mg}$ using atomic absorption spectrophotometer (Murphy and Riley, 1962).

Total organic C (TOC) content of sediments was determined by wet oxidation (Bao, 2000). The sediment $\mathrm{pH}$ was determined in a $1: 2$ (sediment/ water) mixture after a $30-\mathrm{min}$ equilibration. The particle size distributions of the sediments were determined with the Lasac Particle Sizer (Mastersizer 2000, Malvern, U.K.).

\subsection{Adsorption isotherms}

Batch incubation experiments were performed to determine $P$ sorption characteristics of pond sediments. $1 \mathrm{~g}$ of each sediment was placed in a $50-\mathrm{ml}$ plastic centrifuge tube and treated with $20 \mathrm{ml}$ of 0.01 $\mathrm{mol} / \mathrm{L} \mathrm{KCl}$ solutions containing several levels of $\mathrm{P}(0$, $0.05,0.1,0.5,1.0,5,10,50,100 \mathrm{mg} / \mathrm{L})$ as $\mathrm{KH}_{2} \mathrm{PO}_{4}$. Two drops of chloroform were added to each tube during the equilibration period to eliminate the effects of microorganisms. Thereafter, the tubes were sealed, and shaken for a 24-h equilibration in the dark using an end-over-end mechanical shaker at $(25 \pm 3)^{\circ} \mathrm{C}$. Following equilibration, sediment samples were allowed to settle for about $1 \mathrm{~h}$, and then the supernatant was removed and filtered through a 0.45 - $\mu \mathrm{m}$ membrane filter. Filtrates were determined for soluble reactive phosphorus (SRP) by the ascorbic acid method (Murphy and Riley, 1962). Phosphate that disappeared from the solution was considered to be adsorbed by sediments.

The $\mathrm{P}$ sorption index (PSI), a rapid means to estimate $\mathrm{P}$ sorption capacity (Bache and Williams, 1971) was determined for the pond sediments. The method was: $20 \mathrm{ml}$ of a $75-\mathrm{mg} / \mathrm{L}$ solution, prepared by dissolved $\mathrm{KH}_{2} \mathrm{PO}_{4}$ in $0.01 \mathrm{~mol} / \mathrm{L} \mathrm{KCl}$, was added to 1 $\mathrm{g}$ of sediment and equilibrated for $24 \mathrm{~h}$ (Sims, 2000). After equilibration for $18 \mathrm{~h}$ filtrates were determined for SRP by the ascorbic acid method (Murphy Riley, 1962).

\subsection{Sorption parameter calculations}

Sorption parameters were calculated using
Langmuir isotherms as follows (Reddy et al., 1998):

$$
C / S=1 / k \times S_{\max }+C_{d} / S_{\max }
$$

Where $S_{\max }$ is P sorption maximum $(\mathrm{mg} / \mathrm{kg})$ and $k$ is a constant related to $\mathrm{P}$ bonding energy $(\mathrm{L} / \mathrm{mg}) . \mathrm{C}$, is the solution $\mathrm{P}$ concentration measured after a 24-h equilibration $(\mathrm{mg} / \mathrm{L}) . S$ is the total adsorbed $\mathrm{P}$ in sediment (mg/kg).

$$
S=S^{\prime}+S_{0}
$$

Where $S^{\prime}$ is the amount of added $P$ adsorbed by sediment $(\mathrm{mg} / \mathrm{kg})$, and $S_{0}$ is the initial or native sorbed $P$ in sediment $(\mathrm{mg} / \mathrm{kg})$.

By plotting $C_{i} / S$ vs. $C_{t}$, the slope is equal to $1 / S_{\max }$ and the intercept is equal to $1 / k \times S_{\max }$. The phosphorus sorption index (PSI) was calculated as follows (Sims, 2000):

$$
\text { PSI }(\mathrm{L} / \mathrm{kg})=X / \log C
$$

Where $X$ is the amount of added $\mathrm{P}$ adsorbed by sediments $(\mathrm{mg} / \mathrm{kg}) ; C$ is $P$ concentration at equilibrium $(\mathrm{mg} / \mathrm{L})$ after equilibration of a $1-\mathrm{g}$ of sediments with $20 \mathrm{ml}$ of $75 \mathrm{mg} / \mathrm{L}$ phosphate solution on an end-over-end shake for $24 \mathrm{~h}$.

Statistical analysis and regression analysis were done using the Origin software.

\section{Results}

\subsection{Physico-chemical characteristics of PCS sedi-} ments

Pond sediment $\mathrm{pH}$ in PCS ranged from 4.2 to 6.5 indicated significant acidity (Table 2). There was no significant difference between the top organic layers and subsurface layers.

$\mathrm{Fe}_{\mathrm{ox}}$ of the pond sediments in PCS were very high (>5000 mg/kg), with the top $\mathrm{Fe}_{\mathrm{ox}}$ concentrations generally higher than the subsurface layer values. The oxalate-extractable $\mathrm{Al} \quad\left(\mathrm{Al}_{\mathrm{ox}}\right)$ concentrations were lower than $\mathrm{Fe}_{\mathrm{ox}}$ concentrations and generally only $20 \%$ of the $\mathrm{Fe}_{\mathrm{ox}}$ suggesting that $\mathrm{Fe}_{\mathrm{ox}}$ was probably the more important factor than $\mathrm{Al}_{\mathrm{ox}}$ in regulating $\mathrm{P}$ sorption in the pond chain structure (Reddy et al., 1998).

Total organic carbon (TOC) contents of pond sediments ranged from 9.7 to $20.9 \mathrm{~g} / \mathrm{kg}$, and the top TOC concentrations were higher than the subsurface layer values. The highest TOC content was found in the sediments of Pond 1, and the lowest was in the Pond 5, whether the top layers or the subsurface layers. A strong correlative relationship was obscrved between $\mathrm{TOC}$ and $\mathrm{Fe}_{\mathrm{ox}}$ (Fig.2), suggesting that Fe-organic matter complexes could probably play an important role in controlling $\mathrm{P}$ sorption capacity in these pond sediments (Darke and Walbridge, 2000).

The most obvious character of sediment physico-chemical changes in the PCS was that tho sediment properties indicated significant gradient changes along the elevation of ponds (Fig.3). Patterns 
Table 2 Selected physico-chemical characteristics of sediments $( \pm S E)$ from the pond chain structure (PCS)

\begin{tabular}{|c|c|c|c|c|c|c|c|c|c|c|}
\hline \multirow{2}{*}{ Type } & \multirow{2}{*}{ Depth, cm } & \multirow{2}{*}{$\begin{array}{c}\text { Water } \\
\text { content, \% }\end{array}$} & \multirow{2}{*}{$\mathrm{pH}$} & \multirow{2}{*}{ TOC, g/kg } & \multirow{2}{*}{ Clay, $\%$} & \multicolumn{2}{|c|}{ Mehlich I extract, $\mathrm{mg} / \mathrm{kg}$} & \multicolumn{3}{|c|}{ Oxalate extract, $\mathrm{mg} / \mathrm{kg}$} \\
\hline & & & & & & $\mathrm{Ca}$ & $\mathrm{Mg}$ & $\mathrm{Fe}$ & $\mathrm{Al}$ & $P$ \\
\hline \multirow[t]{3}{*}{ Pond 1} & $0-3$ & 43.3 & 4.25 & 20.9 & 8.0 & 4830 & 355 & 9182 & 1400 & 174 \\
\hline & $3-12$ & 37.8 & 4.26 & 18.3 & 7.3 & 4917 & 330 & 3572 & 1139 & 135 \\
\hline & Mean $\pm S E$ & $39.2 \pm 2.1$ & $4.26 \pm 0.09^{*}$ & $18.9 \pm 1.2^{*}$ & $7.5 \pm 0.3^{*}$ & $4895 \pm 286^{*}$ & $336 \pm 14^{*}$ & $7974 \pm 471^{*}$ & $1204 \pm 74$ & $145 \pm 10^{*}$ \\
\hline \multirow[t]{3}{*}{ Pond 2} & $0-3$ & 36.5 & 4.30 & 17.0 & 10.7 & 4945 & 395 & 8209 & 1004 & 197 \\
\hline & $3-12$ & 28.4 & 4.28 & 12.4 & 10.6 & 4972 & 338 & 7355 & 1296 & 178 \\
\hline & Mean $\pm S E$ & $30.5 \pm 2.2$ & $4.28 \pm 0.03^{\circ}$ & $13.5 \pm 1.8^{\circ}$ & $10.6 \pm 0.8^{*}$ & $4965 \pm 173^{*}$ & $365 \pm 15^{*}$ & $7568 \pm 364^{*}$ & $1223 \pm 93$ & $182 \pm 15^{\circ}$ \\
\hline \multirow[t]{3}{*}{ Pond 3} & $0-3$ & 35.3 & 5.54 & 13.6 & 10.7 & 6280 & 495 & 6120 & 1253 & 91 \\
\hline & $3-12$ & 27.4 & 5.40 & 10.5 & 11.1 & 6205 & 455 & 5228 & 1100 & 96 \\
\hline & Mean $\pm S E$ & $29.4 \pm 2.9$ & $5.44 \pm 0.05^{*}$ & $11.5 \pm 1.2^{*}$ & $10.9 \pm 0.3^{*}$ & $6230 \pm 169^{*}$ & $465 \pm 20^{\circ}$ & $5451 \pm 273^{\circ}$ & $1138 \pm 67$ & $95 \pm 1^{*}$ \\
\hline \multirow[t]{3}{*}{ Pond 4} & $0-3$ & 35.5 & 4.84 & 13.0 & 12.9 & 6745 & 455 & 6329 & 1482 & 113 \\
\hline & $3-12$ & 32.4 & 4.74 & 9.97 & 13.1 & 5632 & 472 & 6475 & 1433 & 128 \\
\hline & Mean $\pm S E$ & $33.2 \pm 0.8$ & $4.77 \pm 0.03^{*}$ & $10.7 \pm 1.1^{*}$ & $13.0 \pm 0.4^{*}$ & $6525 \pm 510^{*}$ & $468 \pm 14^{*}$ & $6438 \pm 103^{\circ}$ & $1445 \pm 30$ & $124 \pm 8^{*}$ \\
\hline \multirow[t]{3}{*}{ Pond 5} & $0-3$ & 30.7 & 6.64 & 10.7 & 12.6 & 8520 & 510 & 5977 & 1424 & 93 \\
\hline & $3-12$ & 28.7 & 5.83 & 9.7 & 15.6 & 7980 & 560 & 5511 & 1431 & 135 \\
\hline & Mean $\pm S E$ & $29.3 \pm 0.7$ & $6.27 \pm 0.24^{*}$ & $10.2 \pm 0.5^{\prime \prime}$ & $14.1 \pm 1.5^{\circ}$ & $8250 \pm 270^{*}$ & $535 \pm 25^{*}$ & $5744 \pm 233^{\circ}$ & $1427 \pm 3$ & $114 \pm 21^{*}$ \\
\hline
\end{tabular}

Note: ${ }^{*}$ Mean values $(0-12 \mathrm{~cm})$ are significant at the $5 \%$ level among ponds

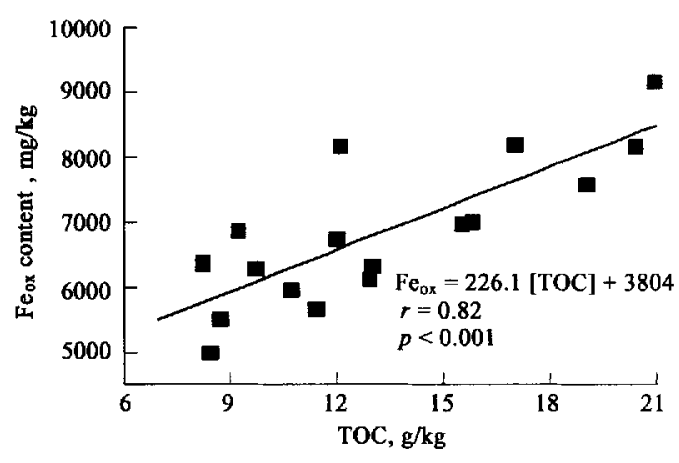

Fig.2 Relationship between oxalate-extractable $\mathrm{Fe} \quad\left(\mathrm{Fe}_{\mathrm{nx}}\right)$ and total organic matter (TOC) of the pond sediments

of spatial variation in water content, $\mathrm{TOC}$ and $\mathrm{Fe}_{\mathrm{ox}}$ of pond sediments were similar along the landscape gradient from foothill to riverside. There was a general decline with increasing distance from the foothill pond

Sorption parameters of ponds for top $0-3 \mathrm{~cm}$ layers
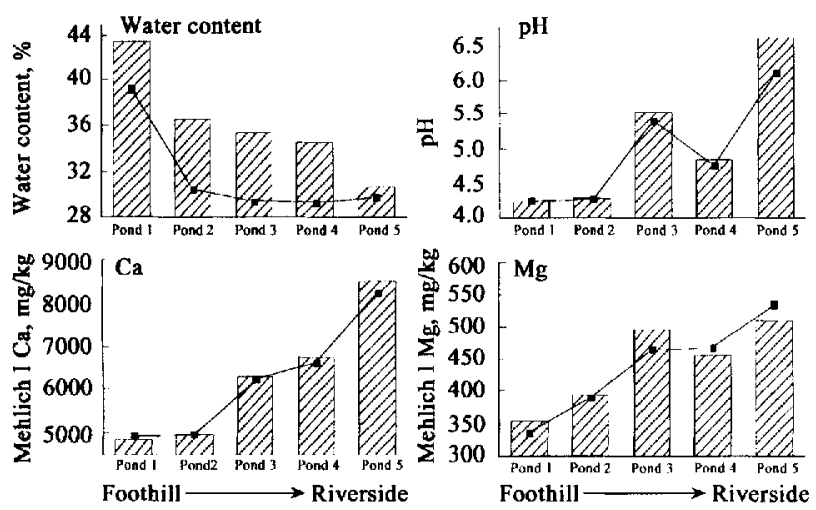

(pond 1) to riverside pond (pond 5). But $\mathrm{pH}$, Mehlich I-extractable $\mathrm{Ca}, \mathrm{Mg}$ and clay were just the contrary. From foothill to riverside there was a general rise. However the spatial variation of Al was not significant (Fig.3).

\subsection{Phosphorus sorption characteristics of PCS} sediments

The main purpose of applying adsorption equations to $\mathrm{P}$ adsorption curves is to understand the processes involved in $\mathrm{P}$ adsorption and to summarise many results by a few numbers (Barrow, 1984). To achieve this purpose, the concentration of $\mathrm{P}$ in the equilibrium solution was related to $\mathrm{P}$ adsorption (Fig. 4). As shown in Fig.4, phosphorus sorption characteristics for sediments from the pond chain structure were generally well described by the Langmuir isotherm even though the pond sediments were complex heterogeneous systems $\left(r^{2}=0.97-0.99\right)$ (Pant and Reddy, 2001).

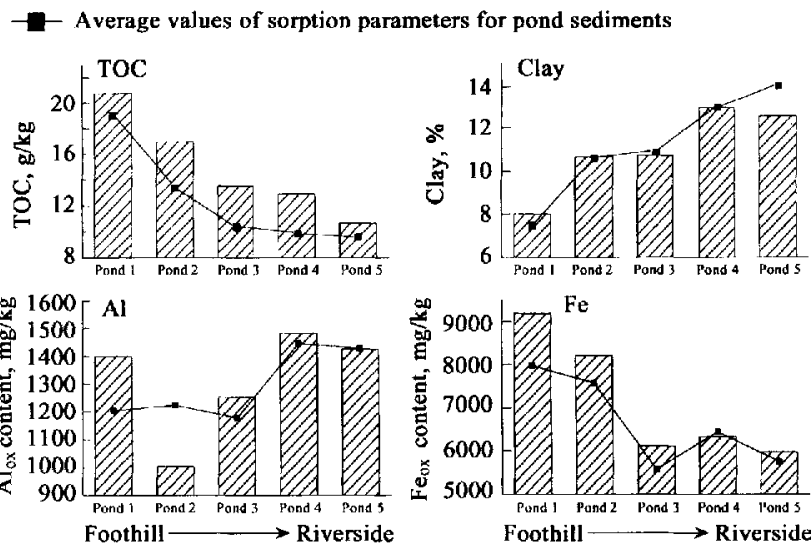

Fig.3 Changes of physico-chemical characteristics of sediments in the pond chain structure (PCS) along a foothill to riverside gradient 

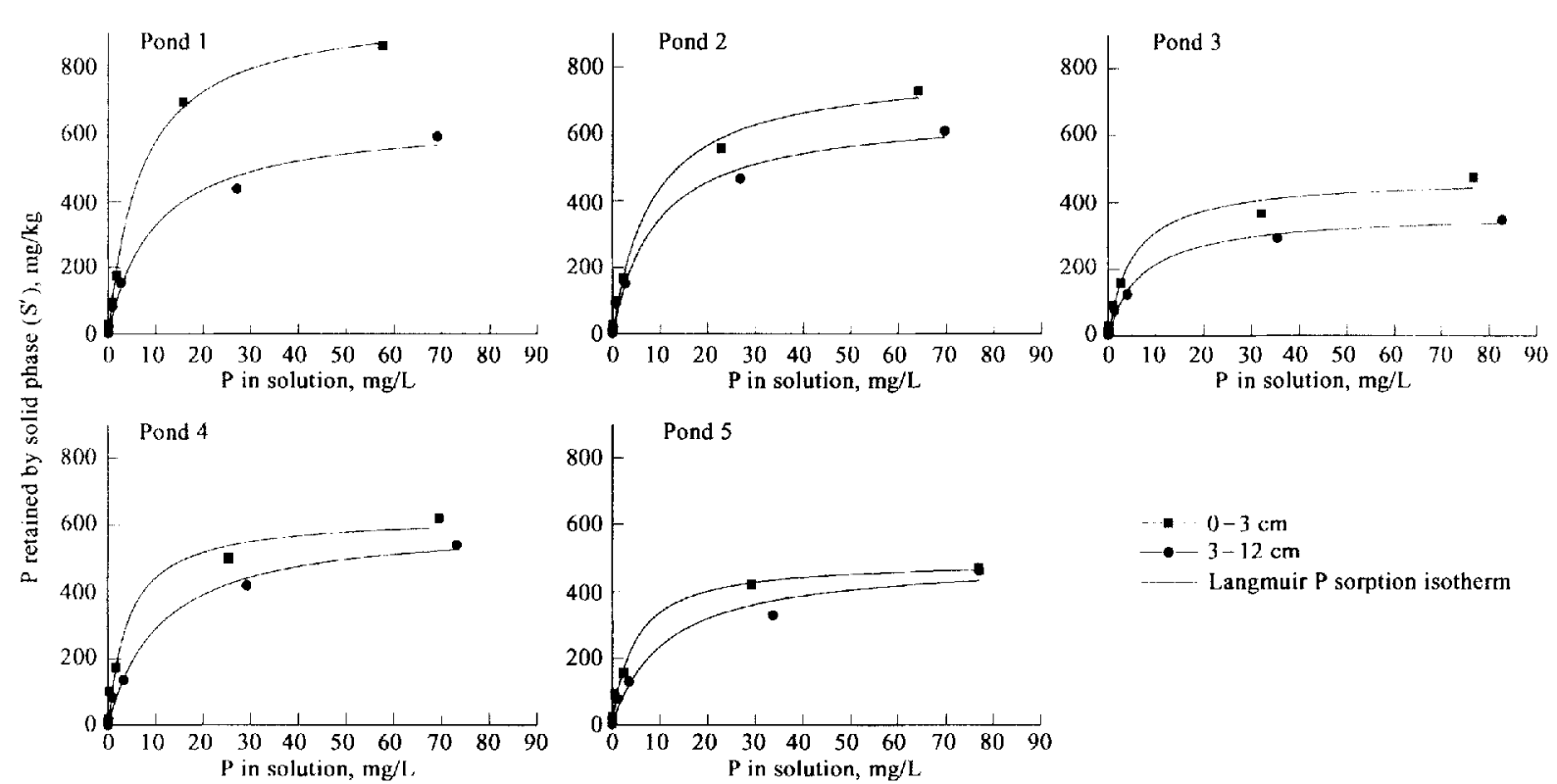

Fig.4 Relationship between $P$ adsorbed by the solid phase and equilibrium $P$ solution for top layer $(0-3 \mathrm{~cm})$ and subsurlace layer $(3-12 \mathrm{~cm})$ of the pond chain strueture

In this study, we use P sorption index (PSI) to estimate the $P$ sorption capacities of pond sediments. A strong relationship was observed between the PSI and $S_{\max }$ (Fig.5). The PSI was about half of the $S_{\max }$. Mozaffari and Sims (1994) found a similar correlation between the PSI and $S_{\max } \quad\left(r=0.97\right.$, except when $S_{\max }>$ $1400 \mathrm{mg} / \mathrm{kg}$ ). Estimating the PSI is not only less time-consuming than developing $P$ sorption isotherms, it facilitates comparisons with related sediment physico-chemical parameters. Our results indicated that PSI also could be used in researches of pond sediments and could be a reliable and easily used method to rank sediments with respect to $\mathrm{P}$ sorption capacity.

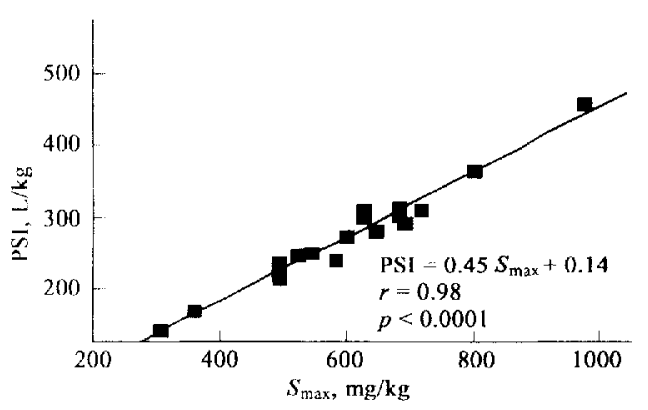

Fig.5 Relationship between the P sorption index (PSI) and sorption maxima $\left(S, S_{\text {mal }}\right)$ as calculated by the Langmuir equation

For the top sediments PSI values ranged from 238 to $457 \mathrm{I} / \mathrm{kg}$ with a mean value of $324 \mathrm{~L} / \mathrm{kg}$. In the subsurface sediments the range in PSI was 218 to 301 $\mathrm{L} / \mathrm{kg}$ and the mean value was significantly lower than that determined for the top sediments (Table 3 ).

Fig. 6 indicates a significant gradient variability of $P$ sorption capacities in the pond chain strueture from
Table 3 Phosphorus sorption characteristics of the pond sediments $( \pm S E)$ by Langmuir model

\begin{tabular}{|c|c|c|c|c|c|}
\hline Type & Depth. cm & $S_{\text {nim }}, \mathrm{mg} / \mathrm{kg}$ & $k, \mathrm{~L} / \mathrm{mg}$ & PSI, Likg & $i$ \\
\hline \multirow[t]{3}{*}{ Pond 1} & $0--3$ & $9741 \pm 60.8$ & $0.15 \pm 0.011$ & $456.8 \pm 23.2$ & 0.99 \\
\hline & $3-12$ & $647.6 \pm 52.7$ & $0.10 \pm 0.009$ & $289.1 \pm 19.1$ & 0.98 \\
\hline & Mean $\pm S E$ & $729.2 \pm 89.8^{\circ}$ & $0.12 \pm 0.013$ & $331.0 \pm 44.1^{*}$ & \\
\hline \multirow[t]{3}{*}{ Pond 2} & $0-3$ & $799.8+26.3$ & $0.12 \pm 0.015$ & $364.9 \pm 8.6$ & 0.99 \\
\hline & $\begin{array}{ll}3 & 12\end{array}$ & $666.5 \pm 20.4$ & $0.11 \pm 0.018$ & $301.4 \pm 6.1$ & 0.98 \\
\hline & Mean $\pm S E$ & $700.0 \pm 36.3^{\circ}$ & $0.12 \pm 0.013$ & $317.2 \pm 16.5^{\circ}$ & \\
\hline \multirow[t]{3}{*}{ Pond 3} & $0-3$ & $522.2 \pm 52.6$ & $0.15 \pm 0.010$ & $247.8 \perp 21.6$ & 0.99 \\
\hline & $3-12$ & $493.9 \pm 41.9$ & $0.10 \pm 0.018$ & $231.3 \pm 20.4$ & 0.98 \\
\hline & Mean $\pm S E$ & $508.1 \pm 14.1^{*}$ & $0.14 \pm 0.019$ & $239.6 \pm 8.3^{*}$ & \\
\hline \multirow[t]{3}{*}{ Pond 4} & $0-3$ & $626.8=20.7$ & $0.24 \pm 0.015$ & $311.9 \pm 13.5$ & 0.97 \\
\hline & $3-12$ & $609.5 \div 18.0$ & $0.09 \pm 0.017$ & $265.9 \pm 12.7$ & 0.98 \\
\hline & Mean $\pm S F$ & $613.8 \pm 14.1^{\circ}$ & $0.13 \pm 0.04$ & $277.4 \pm 14.6^{\circ}$ & \\
\hline \multirow[t]{3}{*}{ Pond 5} & $0-3$ & $492.6 \pm 13.5$ & $0.22 \pm 0.017$ & $237.9 \pm 5.8$ & 0.99 \\
\hline & $3-12$ & $491.8 \pm 11.3$ & $0.09 \pm 0.015$ & $218.1+4.5$ & 0.97 \\
\hline & Mean $\pm S F$ & $492.2 \pm 0.4^{*}$ & $0.16 \pm 0.065$ & $227.9 \pm 9.9^{\circ}$ & \\
\hline
\end{tabular}

foothill ponds to riverside ponds. The sediments of Pond 1 exhibited the greatest P sorption capacity (PSI and $S_{\text {max }}$ ). From the high elevation ponds to the low elevation ponds, $P$ sorption capacities decreased with the decline of the pond elevation except for Pond 4 (Fig.6). Differently situated ponds in subwatershed might provide different water quality benefits with respect to $\mathrm{P}$ retention-higher $\mathrm{P}$ sorption capacities were found in the higher elevation ponds sediments, the lowest $P$ sorption capacity was in the ponds near the river. 


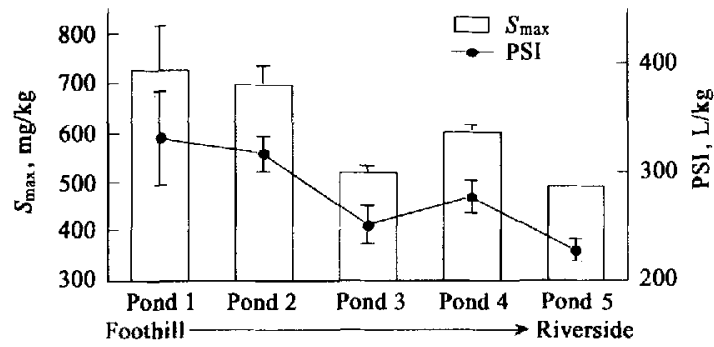

Fig.6 Changes in selccted sorption parameters of surface sediment layers along the elevation of the ponds in the pond chain structure

The spatial change of PSI was consistent with the change of oxalate extractable-Fe along the elevation of ponds (Fig.2 and Fig.6). The most striking relationship was found between PSI and oxalate-extractable Fe ( $r=0.92, p<0.001$; Table 4), which indicated that the distribution of oxalate-extractable $\mathrm{Fe}$ in the pond chain structure can probably control the $\mathrm{P}$ sorption capacity. Total organic matter (TOC) also was positively correlated with PSI, but correlation coefficient was significant less than $\mathrm{Fe}_{\mathrm{xx}}(r=0.71$, $p<0.01$ ) (Table 4), suggesting the importance of $\mathrm{Fe}_{\mathrm{ox}}$ in regulating $\mathrm{P}$ sorption capacity in the pond chain structure. No relationship was found between other sediment properties and PSI, such as $\mathrm{Al}_{\mathrm{ox}}$, Mehlich I-extractable $\mathrm{Ca}$, Mehlich I-extractable $\mathrm{Mg}$ and clay percentage $(p>0.05)$.

Table 4 Correlation coefficients of $P$ sorption capacities and associated physico-chemical properties of pond sediments $(n=17)$

\begin{tabular}{|c|c|c|c|c|c|c|c|c|}
\hline $\begin{array}{l}\text { Para- } \\
\text { meter }\end{array}$ & $\mathrm{pH}$ & Clay & $\begin{array}{c}\text { Mehlich } \\
\text { l-Mg }\end{array}$ & $\begin{array}{c}\text { Mehlich } \\
\text { J-Ca }\end{array}$ & $\mathrm{Ox}-\mathrm{Fe}$ & Ox-Al & $\begin{array}{c}\mathrm{Ox}-(\mathrm{Fe} \\
+\mathrm{Al})\end{array}$ & TOC \\
\hline PSI & NS & NS & NS & NS & $0.92^{\circ *}$ & NS & $0.94^{*}$ & $0.71^{*}$ \\
\hline$S_{\max }$ & NS & NS & NS & NS & $0.94^{* *}$ & NS & $0.95^{* *}$ & $0.74^{\circ}$ \\
\hline
\end{tabular}

Notes: $" p<0.01 ; "{ }^{*} p<0.001$; NS. not significant $(p>0.05)$

\section{Discussion}

\subsection{Physico-chemical characteristics of PCS sediments}

The hydrologic linkages of water storage structures in watersheds can influence the biogeochemical processes of sediments, and can further influence the retention characteristics and function of sediments (Darke and Walbridge, 2000).

Every pond in the PCS has its own catchment (Fig.1). In general, the ponds only receive the nonpiont source runoffs and irrigation runoffs of their own catchments (discontinuous runoff). But when huge precipitations and irrigations happened, the ponds also can receive the runoffs of upstream catchments and effluent of upper ponds (continuous runoff) (Shan et al., 2002). Therefore the pond chain structure is a half-connectivity structure. Because of the direction of runoffs, higher level ponds had important influence on the lower level ponds, while the lower level ponds had no significant influence on their up-level ponds. With the pond effluents and irrigation runoffs from the above level ponds to lower level ponds, the material exchanges happened between the ponds (Shan et $a l ., 2002$ ). This kind of runoff character has important influence to the characters of pond sediments.

The pond chain structure we researched is located in the typical agriculture watershed in the southeast of China and the soil is typical acidic laterite. The composition of clay minerals is kaolinite, hematite and ilmenite etc. (Zhu, 1982). The main source of pond sediments is storm runoffs from ambient land uses, resulting in the acidity of pond sediments. Higher Mehlich I-extractable $\mathrm{Ca}, \mathrm{Mg}$ concentrations were found in the lower elevation ponds, which was probably due to the high acidic $\mathrm{pH}$ conditions of the sediments (Reddy et al., 1998).

The higher concentrations of TOC found in the top layers were understood because of the decomposition of organic materials under anaerobic conditions (Reddy et al., 1998). As shown in Table 1, there were a lot of aquatic plants in the PCS except for pond 3 , and the species and coverage kept approximately steady. The biomass could reach $2 \times$ $10^{5} \mathrm{~kg} / \mathrm{a}$ in PCS (wet weight, data in 2002). But the difference of pond aquatic plants seemed to have no influence to the spatial changes of sediment TOC (Fig. 2). Although there were no aquatic plants in the pond 3, TOC in its sediment was still higher than in pond 4 and pond 5 which had a mass of plants. This indicated that the influent from ambient land uses had an important influence on the spatial characters of pond sediments. The aquatic plants in the ponds had no obvious influence on the TOC contents of the pond sediments. Be different from other large wetland systems, there was strong interaction between the pond and ambient land uses because the ponds were very small compared with the ambient land uses-the area of ponds was only $8 \%$ of the subwatershed. The differences of TOC in the pond sediments were caused by the extraneous sources. Higher TOC contents in pond 1 probably accounted for the high organic matter concentration of influent from the forest soil, which was abundant in humus horizon composed of the decomposed litter of pine trees (Yan et al., 1998). Lower TOC contents in the downstream pond sediments in the PCS suggested that during the storm runoffs flowed from high elevation ponds to low elevation ponds, the pond sediments could function as effective sinks for TOC (Reddy $e t a l ., 1998$ ).

Fig.2 indicates TOC had positively correlated with $\mathrm{Fe}_{\mathrm{ix}}$ in pond sediments, suggesting that TOC may play important role in controlling the biogeochemistry 
and spatial distribution of $\mathrm{Fe}_{\mathrm{ox}}$ in watersheds (Darke and Walbridge, 2000; Reddy et al., 1998). In fact, $\mathrm{Fe}^{3+}$ in solution can bind with organic matter(OM) to form an OM-Fe complex, and influence the $P$ sorption capacity of pond sediments. Fig. 2 indicates $\mathrm{Fe}_{\mathrm{ox}}$ generally decreased with the decline of pond elevations. Similarly to TOC, the pond sediments also could function as effective sinks for $\mathrm{Fe}_{\mathrm{ax}}$ from high elevation ponds to low elevation ponds. The spatial changes of physico-chemical characteristics of PCS were a kind of long-term effects of hydrology (Darke and Walbridge, 2000).

\subsection{Phosphate sorption characteristics of PCS sediments}

The oxalate-extractable $\mathrm{Fe}$ and $\mathrm{Al}$ represent amorphous and poorly crystalline forms, which are important in regulating $\mathrm{P}$ sorption in the acidic soil watersheds (Reddy el al., 1998; Loeppert Inskeep, 1996). Although $\mathrm{Ca}$ and $\mathrm{Mg}$ could also adsorb $\mathrm{P}$, the formation of recalcitrant $P$ compounds including apatite permanently sequesters $P$ (Ruttenberg and Berner, 1993), which could be dominant in oceanic systems and estuaries and not important in PCS acidic sediments. Researches had been reported both crystalline and poorly crystalline $\mathrm{Fe}$ oxides could sorb $\mathrm{P}$ by the same mechanism, but amorphous and poorly crystalline forms tend to dominate sediment $\mathbf{P}$ sorption reactions when present in significant amounts because of their greater reactive surface area per unit sediment volume (Axt Walbridge, 1999; Schwertmann and Yaylor, 1989; Freese ef al., 1992).

We found a strong positive correlation between the PSI and $\mathrm{Fe}_{\mathrm{ox}}$ in the PCS (Table 4), but no significant correlation was found between the PSI and $\mathrm{Al}_{\mathrm{ox}} \quad(p>0.05)$. Even though TOC was also positive correlated with the PSI and $\mathrm{Fe}_{v x}$, while the stepwise multiple regression analysis indicated $\mathrm{Fe}_{\mathrm{ox}}$ was the most important factor controlling $\mathrm{P}$ sorption capacity in the PCS and could explain $85 \%$ of the variation of PSI:

$$
\mathrm{PSI}=0.056\left[\mathrm{Fe}_{\mathrm{ox},}\right]-106, p<0.001, R^{2}=0.85, S E=28.9
$$$$
\text { (PSI: } \mathrm{L} / \mathrm{kg} ; \mathrm{Fe}_{\mathrm{ox}}: \mathrm{mg} / \mathrm{kg} \text { ) }
$$

Two-term model of $\mathrm{Fe}_{\mathrm{ox}}$ and $\mathrm{Al}_{\mathrm{ox}}$ was slightly better than $\mathrm{Fe}_{\mathrm{ox}}$ alone ( $r=0.94$; Table 4 ). In general, the sum of $\mathrm{Fe}_{\mathrm{ux}}+\mathrm{Al}_{\mathrm{ux}}$ was a better predictor of $\mathrm{P}$ sorption capacity than either $\mathrm{Fe}_{\mathrm{ox}}$ or $\mathrm{Al}_{\mathrm{ox}}$ alone (Darke el al., 2000). The high $\mathrm{Fe}_{\mathrm{ax}}$ content and high $\mathrm{Fe}_{0 \mathrm{x}}$ : $\mathrm{Al}_{\mathrm{ox}}$ ratio might be the reason that $\mathrm{Fe}_{\mathrm{ox}}$ was more important than $\mathrm{Al}_{i \mathrm{~K}}$ in controlling $\mathrm{P}$ sorption in PCS.

$\mathrm{Fe}_{i,}$ was positively correlated with sediment organic matter (Fig.3), suggesting that organic matter-metal (Fe, $\mathrm{Al})$ complexes, which are also extracted by acid ammonium oxalate, may provide an important component of the $\mathrm{P}$ sorption capacity in PCS sediments. Humic Fe complexes provide important $P$ sorbing sites (i.e., $\mathrm{PO}_{4}{ }^{3-}$ was bound to the organic matter via Fe ligands; Gerke and Jungk, 1991). Fe freshly complexed with humic substances can sorb 10 times morc $P$ than noncrystalline $\mathrm{Fe}_{\mathrm{ow}}$ (Gerke and Hermann, 1992). In addition, organic matter probably could inhibit the crystallization of $\mathrm{Fe}$, which in turn could increase $\mathrm{P}$ sorption as noncrystalline $\mathrm{Fe}_{\mathrm{ox}}$ would sorb more $\mathrm{P}$ than well-crystallined (Borggaard et al., 1990). Thus, the presence of OM-Fe complexes could significantly increase the P sorption capacity of the PCS.

The spatial variability of PSI was similar to the $\mathrm{Fe}_{\mathrm{ux}}$ and TOC of pond sediments (Fig.3 and Fig.6). P sorption capacity in the pond 1 was the highest. The surface runoffs entering pond 1 mainly came from the hill forest, and the $\mathrm{P}$ concentration of influent was generally lower than that from rice or nonirrigated farmlands (Yan et al., 1998). Higher P load might decrease the P sorption capacity (Nair et al., 1998). In addition, pond $I$ had the greatest $\mathrm{Fe}_{\mathrm{ox}}$ and TOC. We call these two factors as exterior factor (influent $\mathrm{P}$ concentration) and interior $\left(\mathrm{Fe}_{\mathrm{ox}}, \mathrm{Al}_{\mathrm{sx}}\right.$ or TOC contents in sediments). Under the common controlling of exterior and interior factors, pond indicated different $P$ sorption capacity and spatial characteristics. Because the PCS is a half-connectivity structure, the catchments of downstream ponds should include not only their own catchments but also the catchments of upstream ponds (continuous runoff). The downstream ponds had higher potential $\mathbf{P}$ loading, in addition, downstream ponds generally had lower $\mathrm{Fe}_{\mathrm{ox}}$ and $\mathrm{TOC}$ contents, resulting in the $\mathrm{P}$ sorption capacities of ponds generally declining with the elevations of pond in PCS.

Spatial variability in hydrologic and sediment inputs can affect the distribution of sediment constituents that are important in P sorption (Johnston, 1991). Our data agreed with these studies, and further indicated that under long-term hydrologic and sediment inputs, the different wetland systems arranged in a certain order also showed significant gradient variability of sediment characteristics and $P$ sorption capacities. Spatial variability of $P$ sorption capacity was mainly due to the spatial changes of correlative sediment parameters such as $\mathrm{Fe}_{o x}$ and TOC. There was no research about $P$ sorption characteristics of different arrangement structures of wetlands in watersheds. Our research indicated that the situation of ponds had important influence on the $\mathrm{P}$ sorption capacity of sediments and the riparian wetlands (such as the PCS) were not homogenous units of $\mathrm{P}$ sorption capacity in watersheds. Under the long-term effects of hydrology, they could indicate significant spatial changes, such as physico-chemical properties and $P$ sorption capacities in the PCS (Fig.3 and Fig.6). The P sorption capacities declined from foothill to riverside, 
and the higher the ponds are, the stronger the $P$ sorption capacities are. It is not correct to consider riparian wetlands as homogenous units in terms of their ability to remove nonpoint source $P$ pollutant from surface runoffs.

\section{Conclusions}

As the basic linking units of the multipond system, the PCS can effectively control nonpoint source $P$ pollutant of agricultural watersheds. They can act as a multi-level treatment system in protecting downstream waters from nonpoint source $P$ inputs.

Variation in $\mathrm{P}$ sorption capacity was largely explained by a few basic pond sediment characteristics. In PCS, $\mathrm{Fe}_{\mathrm{ox}}$ was the key factor in controlling $\mathrm{P}$ sorption capacity and could explain $85 \%$ of the variation in the PSI. The strong correlative relationship between $\mathrm{Fe}_{\mathrm{ox}}$ and TOC suggests the potential role of $\mathrm{Fe}_{\mathrm{ox}}$ organic matter complexes in controlling $\mathrm{P}$ sorption capacity.

Long-term hydrologic and sediment inputs can affect the distribution of sediment constituents and further affect the P sorption capacity. In PCS, from high elevation ponds to low elevation ponds, $\mathrm{Fe}_{\mathrm{ox}}$, TOC generally declined, while $\mathrm{pH}, \mathrm{Ca}$ and $\mathrm{Mg}$ were just the contrary. Under the control of $\mathrm{Fe}_{\mathrm{ox}}$ and $\mathrm{TOC}, \mathrm{P}$ sorption capacity (PSI) also indicated spatial variability-decline with the pond elevation decrease. The highest $P$ sorption capacity was in the ponds at the foothill and the lowest value was in the ponds near the river.

The wetlands in riparian areas should not be considered homogenous units when estimating their $\mathrm{P}$ sorption potentials. Depending on the different pond spatial connectivity, the pond chain structure (PCS) may act as important buffers between agricultural lands and rivers in watersheds.

\section{References:}

Axt J R, Walbridge M R, 1999. Phosphate removal capacity of palustrine forested wetlands and adjacent uplands in Virginia[J]. Soil Sci Soc Am J, 63: 1019-1031.

Bache B W, Williams F G, 1971. A phosphate sorption index for soils [J]. J Soil Sci, 22: 289-301.

Bao S D, 2000. Soil and agricultural chemical analysis [M]. Beijing, China: Chinese Agricultural Publisher.

Barrow N J, 1984. Modelling the effects of $\mathrm{pH}$ on phosphate adsorption by soils[J]. J Soil Sci, 35: 283-297.

Borggaard O K, Jorgensen S S, Moberg J P et $a$., 1990. Influence of organic matter on phosphate adsorption by aluminium and iron oxides in sandy soils[J]. J Soil Sci, 41: 443-449.

Darke A K, Walbridge M R, 2000. Al and Fe biogeochemistry in a floodplain forest: Implications for $P$ retention [J]. Biogeochemistry, 51: 1-32.

Freese D, van der Zee S, van Riemsdijk W H, 1992. Comparisons of different models for $\mathrm{P}$ sorption as a function of Fe and $\mathrm{Al}$ oxides of soil[J]. J Soil Sci, 43: 729-738.

Gerke J, Jungk A, 1991. Separation of phosphorus bound to organic matrices from inorganic phosphorus in alkaline soil extracts by ultrafiltration[J]. Comm Soil Sci Plant Ana!, 22: 1621-1630.

Gerke J, Hermann R, 1992. Adsorption of orthophosphate to
humic-Fe-complexes and to amorphous Fe-oxide [J]. Z Pflanzenernahr Bodenk, 155: 233-236.

Goldberg S, Sposito G, 1985. On the mechanism of specific phosphate adsorption by hydroxylated mineral surfaces: A review [J] Commun Soil Sci Plant Anal, 16: 801-823.

Jin W G, Yin C Q, 1992. Water and matter dynamic balance in the rice field and its overflow estimate model[J]. J of Environ Sciences, 4 (2): $95-101$

Johnston C A, 1991. Sediment and nutrient retention by freshwater wetlands: effects on surface water quality [J]. Crit Rev Env Control, 21: 491-565.

Linker L C, Stigall C G, Chang C H et ol., 1996. Chesapeake Bay watershed model quantifies nutrient loads [J]. J Water Env Tech, Jan: $48-52$.

Lockaby B G, Walbridge M R, 1998. Biogeochemistry[M]. In: Southern forested wetlands (Mmessina M. G., Conner W. H., ed.). Lewis Publishers, Boca Raton, FL. 149-172.

Loeppert R H, Inskeep W P, 1996. Iron [M]. In: Methods of Soil Analysis. Part 3. Chemical Methods (Sparks D. L. et al., ed.). Madison, Wisc: American Society of Agronomy. 639-664.

McCallister K L, Logan T J, 1978. Phosphate adsorption-desorption characteristics of soils and bottom sediments in the Maumee River Basin of Ohio[J]. J Environ Qual, 7: 87-92.

Mozaffari M, Sims J T, 1994. Phosphorus availability and sorption in an atlantic coastal plain watershed dominated by animal-based agriculture[J]. Soil Sci, 157: 97-107.

Murphy J, Riley J P, 1962. A modified single solution method for the determination of phosphate in ratural waters[]]. Anal Chim Acta, $27: 31-36$.

Nair V D, Graetz, D A, Reddy K R, 1998. Dairy manure influences on phosphorus retention capacity of spodosols [J]. J Environ Qual, 27: $522-527$.

Pant H K, Reddy K R, 2001. Phosphorus sorption characteristics of estuarine sediments under different redox conditions [J]. J Environ Qual, 30: 1474-1480.

Reddy K R, O'Connor G A, Gale P M, 1998. Phosphorus sorption capacities of wetland soils and stream sediments impacted by dairy effluent[J]. J Environ Qual, 27: 438-447.

Richardson C J, 1985. Mechanisms controlling phosphorus retention capacity in freshwater wetlands[J]. Science, 228: 1424-1427.

Ruttenberg K C, Berner R A, 1993. Authigenic apatite formation and burial in sediments from non-upwelling, continental margin environments[J]. Geochim Cosmochim Acta, 57: 991-1007.

Schwertmann U, Taylor R M, 1989. Iron oxides[M]. In: Minerals in soi environments (Dixon J. B., Weed S. B., ed.). 2nd ed. Madison, WI: SSSA Book Ser. 1. SSSA, 380-438.

Shan $\mathrm{B} \mathrm{Q}$, Yin C Q, Li G B, 2002. Transport and retention of phosphorus pollutants in the landscape with a traditional, multipond system [J]. Water, Air, and Soil Pollution, 139: 1534.

Sims J T, 2000. A phosphorus sorption index [M]. In: Methods for phosphorus analysis for soils, sediments, residuals and waters (Pierzynski G. M., ed.). Southern Co-operative Series Bulletin No396, North Carolina Co-operative Extension, North Carolina State University, Raleigh, NC. 22-23.

Tu Q Y, Gu D X, Yin C Q et al., 1990. Chaohu Lake eutrophication study $[\mathrm{M}]$. Hefei, China: University Press of Science and Technology of China.

Walbridge M R, 1993. Functions and values of forested wetlands in the Southern United States[J]. J Forestry, 91: 15-19.

Wang W D, Wang D L, Yin C Q, 2002. A ficld study on the hydrochemistry of land/inland water ecotones with reed domination[J]. Acta Hydrochim Hydrobiol, 30 (2/3): 117-127.

Yin C Q, Zhao M, Jin W G et al., 1993. A multi-pond system as a protective zone for the management of lakes in China [J]. Hydrobiologia, 251: 321-329.

Yan W J, Yin C Q, Tang H X, 1998. Nutrient retention by multipond systems: Mechanisms for the control of nonpoint source pollution [J]. J Environ Qual, 27: 1009-1017.

Zhu Z X, 1982. Pedology [M]. Beijing, China: Chinese Agricultural Publisher.

(Received for review Octuber 31, 2005. Accepted December 16, 2005) 